\title{
鋼の異常組織に就て (IV)(輯錄)
}

\section{G.Brophy ${ }^{(28)}$ の鋼の正常性に對する A1の影響に就ての研究}

McQuaid は $0.1 \%$ 前後の $\mathrm{Al}$ は珙常組織の原因であ る, Bain は $0.4 \%$ 以上の $\mathrm{Al}$ を金屬として含有するもの は固體渗炭飞ては巽常組織, 炭化水素沴炭にては正常組 織を呈するてと報告をしてるるが，Brophy は次の如き 萯驗結果を哴告して居る。

電解鐵を $\mathrm{H}_{2}$ 中で 15 分熔融して冷却する，更にての表

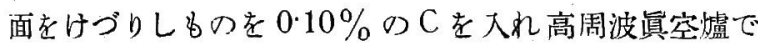

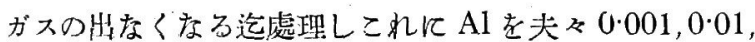
$0 \cdot 10,1 \cdot 00 \%$ の割合飞入北 10 分間标汪蛒融狀態飞保つ. 渗炭處理は $930^{\circ}$ ，市販固體渗炭劑沉て 6 時間， $\mathrm{H}_{2}$ 老 $\mathrm{C}_{6} \mathrm{H}_{6}$ 几泡出させて得たるガスで 10 時間行ひ，同一の速度で

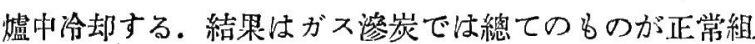

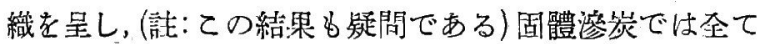
が異常組織で且ての部分に微細粒子の存在を認めた，ガ ス渗炭されをものには微細粒子は全然をい。乙の異常組 織で且微細粒子のある所は Alの增へるにつれ表面から の深さが淺くなつて居る、乙れは渗炭劑より柬る $\mathrm{O}_{2}$ 之 $\mathrm{Al}$ が化合し $\mathrm{Al}_{2} \mathrm{O}_{3}$ 生じ, $\mathrm{Al}$ の增へる亿つ外外ら棑 る $\mathrm{O}_{2}$ は急激に $\mathrm{Al}$ 亿より固定されるからである。 $\mathrm{Al}^{\prime}$ と $\mathrm{O}_{2}$ が結合し翼常組織示した詹の深さは $\mathrm{Al}$ 亿就ての 4 種の銅にて次の如し.

$0.001 \% \mathrm{Al} 0.018 \mathrm{In}, 0.01 \mathrm{~A} 10.015 \mathrm{In}, 0.10 \mathrm{Al} 0.012$ In, $1.00 \mathrm{Al} 0.0045 \mathrm{In}$

以上の結果から巽常組織老起す原因の 1 は $\mathrm{Al}_{2} \mathrm{O}_{3}$ で ある(註: $\mathrm{Al}_{2} \mathrm{O}_{3}$ であると速斷せずと $\mathrm{Al}_{2} \mathrm{O}_{3}$ の生成飞在り と考へる方がよりととが分るが Brophy は不溶解粒子

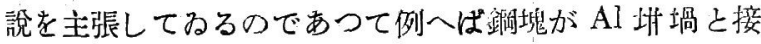
觸した篇几その部分が污染され炭化水素で渗炭されてさ

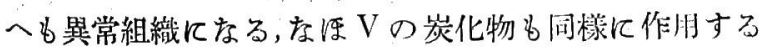
之述へて居る.

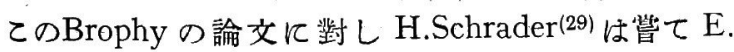
Houdremont ${ }^{(20)}$ と共飞行つを研觉結果から次の如く进 べて居る.

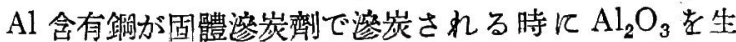
ビ且つ $\mathrm{Al}$ の增へるとつれ $\mathrm{O}_{2}$ の侵入が阻まれると云

(28) G. Brophy, Trans. Amer. Soc. Steel Treat., 25(1937), 315.

(29) H. Schrader, Stahl u.Eisen, 57 (1937), 951.

\section{本 間 正 雄*}

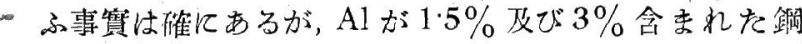
を固體渗炭して为維密な波來土を有する正常組織である こよが Schrader 等の研究で獭認したが(この部分が $\mathrm{Al}_{2} \mathrm{O}_{3}$ の存在する㸴であるか否かに就ては記载してない が該論文揭载の竄畺には介在物の存在圭認める(第 32 圖))，この高 $\mathrm{Al}$ 合金銓で例登された性質から $6 \mathrm{O}_{2}$ の存

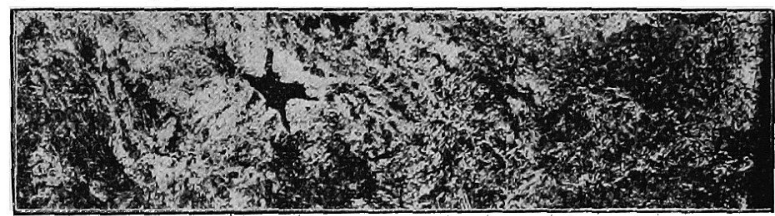

第 32 圖 $0.20 \%$. $0.25 \% \mathrm{Si}, 0.30 \% \mathrm{Mn}, 1 \cdot 70 \% \mathrm{Al}$ の試

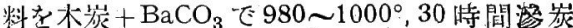
(Houdremont, Schrader)

在に於て少量の $\mathrm{Al}$ が粠常性索與へると云ふてとには同 意出來なん.Brophyの觀察した異常組織は試料とし電 解狳を使的したからこの純粹性のため引き迎されたるの であらう上反駁して居る。

\section{G. Derge, A. Kommel, R.Meh1 ${ }^{(30)}$ の䃑究}

高純度錩の大洲时結晶粒の大さに及痤す介在物の影響 を知る目的で研究した。乙の問題に對してなされた今染 の研究は試料注販品走使用して子るので研究目的以外 の介在物の混入により然數の影響する因子老洘虑せ权ば ならなかつたので Derge 等は試料製作は極度に惐重に 行ひ高純度のものに就き硼究しを。鐵は精製された $\mathrm{H}_{2}$ で純粹化したカルボニール鐵を朋ひる,てのものとA1 合金を作る時には高純度 $\mathrm{Al}$ 品鉛跀堝中でアームコ鐵 の管に包み $800^{\circ}$ に於て $\mathrm{H}_{2}$ 氣中で登帶せしめ Fe に落着 せしむるか, 又は 99.3\% Al を電㴋鍍金の方法 (Blue \& Mathers(31)の方法による) で電着せしめた，更に $\mathrm{Al}$ を 全試料中に掂散させる鹞に $1100^{\circ}$, 42 日間, $\mathrm{H}_{2}$ 氣中で燒 鈍した，但しこの處理で中央迄完全に均一にはならなか つたと述べて居る，ての純鐵と $\mathrm{Si}$ 合金を作る時は $99 \%$ $\mathrm{Si}$ で石英管中に Fe 老包み $1200^{\circ} \mathrm{H}_{2}$ 氣中で處理し，更に 均一化するな゙ $1100^{\circ}$ ，59日間， $\mathrm{H}_{2}$ 中で窝散せしめた， $\mathrm{Al}$ の時之同樣中央迄は完全には均一にならなかつた。

(30) G. Derge, A. Kommel, R. Mehl, Trans. Amer. Soc. Metals, 26(1938), 153.

(31) R. Blue, F. Mathers, Trans. Electrochem. Soc., 65 (1934), 339 . 
以上の方法により $\mathrm{Al}, \mathrm{Si}$ は金屬状態で Fe中にあるが, て れ等のもの」酸化された時の影響を看る爲に $\mathrm{H}_{2}-\mathrm{H}_{2} \mathrm{O}$ 混合瓦斯で處理した，即ち水中を通した $\mathrm{H}_{2}$ で $1100^{\circ}$ で 上記の試料の一部分を酸化した，ての處理では $\mathrm{Al}, \mathrm{Si}$ は 酸化されるが Fe 酸化するには理論上餘りに低い檿な のでFeの酸化物になることはない，以上の製作試料か ら次のものを選び滲炭組織を研究した。

a. $\mathrm{Al}$ 電鍍及び攄散處理で作つち $0.07 \% \mathrm{Al}$ カルボ ニール鐵は $925^{\circ}, 48$ 時間 $\mathrm{O}_{2}$ のない炭化水素瓦斯で渗炭 して正常組織㔺した。

b. 同一試料を $\mathrm{H}_{2}-\mathrm{H}_{2} \mathrm{O}$ 瓦斯で酸化したものを $925^{\circ}$, 48 時間 Houghton の No. 50 Pearlit (固體滲炭劑)で渗炭 したものは異常組織を呈した。

c. $0.1 \% \mathrm{Al}$ カルボ 上記の如き $\mathrm{H}_{2}$ 處理はせず $0.1 \sim 0.2 \%$ の $\mathrm{O}_{2}$ を有する, 而 も目空高周波熔解されたもので, $\mathrm{Al}_{1}$ は $\mathrm{O}_{2}$ 上化合し $\mathrm{Al}_{2} \mathrm{O}_{3}$ が分散して存在し微細組織を有するものなり)ての ものを $925^{\circ}, 48$ 時間炭化水素淩炭しで正常組織を與入, 固體滲炭し異常組織を與へた,てのてとよりDerge 等は 異常性は Fe 几固溶せる $\mathrm{O}_{2}$ によ原因されるもので $\mathrm{Al}$ 文は $\mathrm{Al}_{2} \mathrm{O}_{3}$ て依るものでないてとを示すと述べて居る. なほ大洲田結晶粒の大さに關しては、上述の高純度試料で 研究せる結果は

a. 細かく分散した固體粒子は大洲田結晶粒成長を妨 害, 禁止するもので $\mathrm{Al}_{2} \mathrm{O}_{3}$ 又は $\mathrm{SiO}_{2}$ 單獨でこの作用が ある，而して $\mathrm{Al}$ 珪酸監の如く化合することは不必要 である.

b. 固溶せる Al, Si にはての作朋がをい。

c. 結晶粒成長禁止の程度は酸化物の分散してる狀態 により極めて影響される。

\section{T. G. Diǵges ${ }^{(32)}$ の研究}

試料の鐵一炭素合金は次の樣にして造つた,高純度の電 解鐵を面空中で純マグネシャ坼堝で熔かし鈰塊を作りて れを約 $1170^{\circ}$ で $3 / 10$ inの原さに錯鍊して續いて hot rolling で 1/8 in そなし更に cold rolling で 0.040 inの 厚さのものを作る,てれを約 $600^{\circ}$, 青時閒䢐空中で燒純 してから 900 925 で $\mathrm{H}_{2}-\mathrm{C}_{6} \mathrm{H}_{6}$ で滲炭して目的の $\mathrm{C}$ 量 の鐵一炭素合金を作る。次にC索均一几分散せしめるた め眞空中で $900 \sim 925^{\circ}$ 亿 4,5 時間加熱する, 而して粗粒 波又は密な波來土を生ずる程度に充分に早く冷却する， 作成した試料のC 量は $0.23 \sim 1.21 \%$ の間のものである. 顯微笠組織を見るためにてれ等のものを更に $925^{\circ}, 1$ 時 間直空中で燒刢する，共析組成以上のものは標準組織と

(32) T. G. Digges, Trans. Amer. Soc. Metals, 26(1938), 408. Bur. Standards J. Research, 20(1938), 571.
異ならぬ栐に思はれるが，過共析組織のものは一部又は 全部が地鐵にかてま㲹て $\mathrm{Fe}_{3} \mathrm{C}$ の㠜集せるもので明膫な 異常組織を現はす (第 33 圖). 以上の如くして作成した

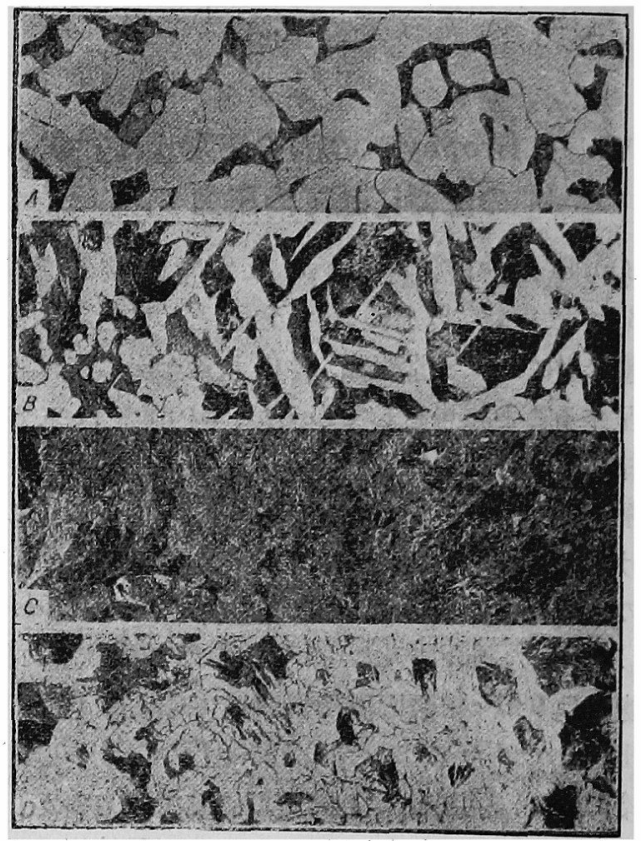

第 33 闾 $\mathrm{C}_{6} \mathrm{H}_{6}-\mathrm{H}_{2}$ 济炭後均一化處理学行ひ 更に覓空中に1時間 $926^{\circ}$ にて燒鈍した組織 (A) $0.23 \%$ C, (B) $0.50 \%$ C, (C) $0.85 \%$ C, (D) $1 \cdot 21 \%$ C.

試料の化學分析，分光分析及び馗空聺融法によるガス分 析の結果を,第9表に示すが, $\mathrm{O}_{2}, \mathrm{~N}_{2}, \mathrm{H}_{2}$ の量は鑰造され

第 9 表

鐵一炭素合金の分析された不純物

\begin{tabular}{|c|c|c|c|}
\hline 元素 & 分光分析 & 化學分析 & 傎空熔融法 \\
\hline $\mathrm{Mn}$ & $\cdots$ & 0.002 & $\ldots \ldots$ \\
\hline P & $\ldots \ldots$ & $<0.001$ & $\ldots \ldots$ \\
\hline $\mathrm{S}$ & & 0.004 & $\ldots \ldots$ \\
\hline $\mathrm{Si}$ & 0.001 & 0.002 & $\ldots \ldots$ \\
\hline $\mathrm{Cu}$ & $<0.001$ & 無 L & .. \\
\hline $\mathrm{Ni}$ & 0.006 & 0.007 & .. \\
\hline Co & $\ldots \ldots$ & 0.007 & $\ldots \ldots$ \\
\hline $\mathrm{Ca}$ & $<0.001$ & $\ldots \ldots$ & $\ldots \ldots$ \\
\hline $\mathrm{Pb}$ & $<0.001$ & $\ldots$ & $\ldots \ldots$ \\
\hline $\mathrm{Mg}$ & $<0.001$ & $\ldots$ & $\ldots \ldots$ \\
\hline $\mathrm{O}_{2}$ & $\ldots$ & $\ldots \ldots$ & 0.003 \\
\hline $\mathrm{N}_{2}$ & $\ldots \ldots$ & $\ldots$ & $0 \cdot 001$ \\
\hline $\mathrm{H}_{2}$ & $\ldots \ldots$ & $\ldots \ldots$ & 0.0002 \\
\hline
\end{tabular}
をものも, 又 その後上述の 處理を受けた bの高純度 鐵及び鐵一炭 素合金飞關せ ず相異はなか つた, $\mathrm{S}, \mathrm{Ni}$, $\mathrm{Co}, \mathrm{O}_{2}$ が主な る不純物でこ れ等の合計は $0.021 \%$ で余 不純物の合計 は 0.031\%である。

てれ新の試料の大洲田粒は全てのCを溶液にする溫 度迄加熱したものに就き決定した，全ての試料は同一の 結昆粒を有し 100 倍の大さで平均 $6 \sim 12$ 粒/ $\mathrm{in}^{2}$ (A.S.T.M 粒數 4)であつた。臨界冷却速度の決定は全てのC溶 解せしめ且同一の結晶粒を與へた $925^{\circ} の$ 溫度から燒入 を行つた，結果は第 34 圆に示す如く，合金の C 量の增す 
につれ陪界泠却速度が減少する過其析のものは亞共析， 共析の合金より大なる hardenabilityを有することを

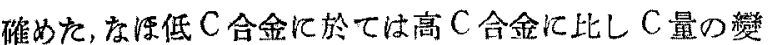

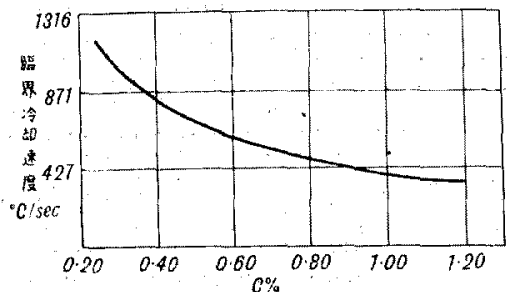

第 34 圆，鐡一炭素合金の装素量と 臨界冷却速度の關俰 化牥臨界冷却 速度に著しい 䌯化を與へ る.

次保一單

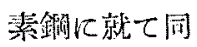
㥞な賽驗を行 つた, 酸性布 蜔法で得た

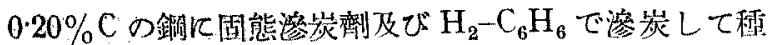
kのC量の試料を作つた， $0.20 \% \mathrm{C}$ の觛の分析表を第 10 表に示士，厚さ $0.050 \mathrm{in}$, 幅 $0.260 \mathrm{in}$ ，長さ $8 \mathrm{in} の b の$ 第 10 表 單一炭素鋼の化學組成 元素 電 量 \%

C. ......... 020

Mn ......... 0.46

P $\ldots \ldots \ldots, 0.043$

S $\ldots \ldots \ldots \ldots 0.025$

$\mathrm{Si} \ldots \ldots \ldots \ldots .15$

Cv $\ldots \ldots \ldots \ldots 002$

$\mathrm{V} \ldots \ldots \ldots \ldots$ 痕跡

$\mathrm{Ni} \quad \ldots \ldots \ldots \ldots(1 \cdot 11$

$\mathrm{Cu} \ldots \ldots \ldots, 0.021$

As $\ldots \ldots \ldots 0012$ 术扊 $85 \%, \mathrm{Ba} \mathrm{CO}_{3} 15 \%$ で $925^{\circ}$ で㵳炭し更に同じ溫度

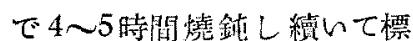
準化の處理を行ふ，後に表面 を除き0.040inの厚さになし このものに就て大洲田粒, 履 界椧却速度の僻觉索行つた， 標準化の處理を行つたもの 試料は何れ女粗粒陂組織 である。 $\mathrm{H}_{2}-\mathrm{C}_{6} \mathrm{H}_{6}$ で渗炭し

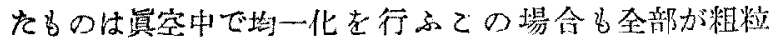
陂組織である，試料の大さは同じで $0.040 \times 0.260 \times 8$ in である。單一炭素敛は同一の大洲田粒圭得るために

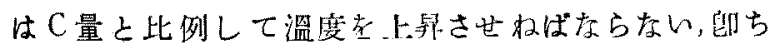
$0.020 \% \mathrm{C}$ の のは $870^{\circ}, 1.20 \% \mathrm{C}$ のもは $926^{\circ}$ で處理 した,大洲时粒は全てのbのに就て一定で 100 倍の倍率 で 6-12 粒 $/ \mathrm{in}^{2}$ (A.S.T.M. 粒數 4) である. 臨界冷却速度 は鐵一炭素合金の場合と同稼に同じ絬晶粠を與人月全炭 素を完圣化固溶する溫度から燒入して研究した。その䋨

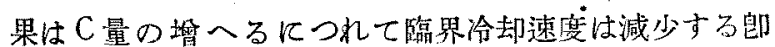

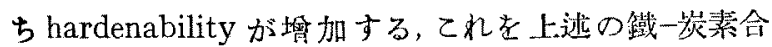
金に比较すると全てのC量のものに就て上り深く硬化 する,てのてとは單一炭素銅に Mn, Si が多く含有されて

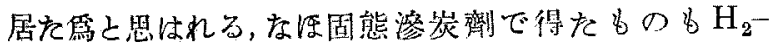

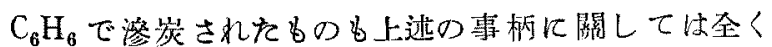
異ることがなかつた。單一炭素銅を连常の燒入温度筙 園から燒大して臨界冷却速度を調べたがての場合は $0.75 \sim 0.80 \% \mathrm{C}$ に至る迄は減少するが， $1.05 \% \mathrm{C}$ 迄は急 激に增加する，1.05 1.40\% Cの間では臨界冷却速度に は變化がない，かくの如く共析組成以上のものになる hardenability の減少することは大洲田粒の相異と大洲
田に溶解して居るC 量の相翼することによるのである。

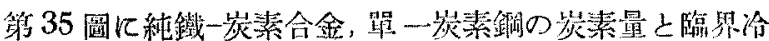

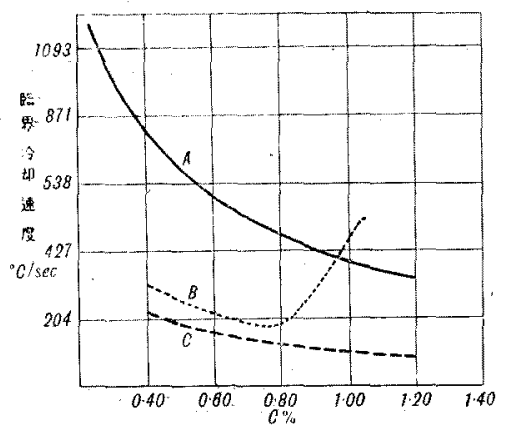

第 35 圖 炭秦量と臨界冷却 潎度の關保 却速度の關係老 示す, A は純鐵 一炭素合金, C注 單一一炭素䑾で何 れ多絬昆粒虹一 起で全炭素完 全に固塎せる狀

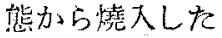
ものである, C \& A 比L hardenabilitiy

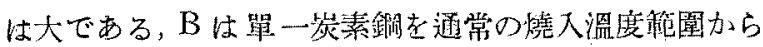
燒入したものである。

\section{XIX。總括}

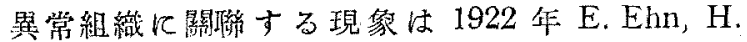
McQuaid 等に依り取上げられて以來多くの研究者によ り探㠰されたものであるが比の如く各研究者により意 見の種タ異つて議論されてるのが今日の狀態である。こ の現堭の研究は㱠ゼ全く米國の學界で行なはれたるので 米國以外では獨逸の Houdremont 一派の人ネが多少の

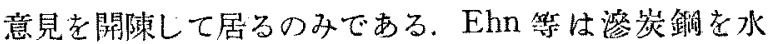

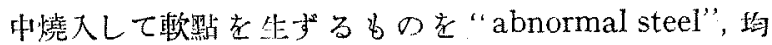
一に硬化するものを“normal steel”之名づけたのであ る,而して“abnormal steel” の鯜入前の組䋨は“normal steel”とは常に異なり時に過北析相にて顯著なる差琵を 見出すのである。即ち“abnormal steel”之“abnormal structure”とは常減䋇して居るものである。

\section{1. 異常鋼の軟點}

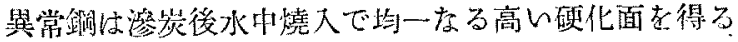

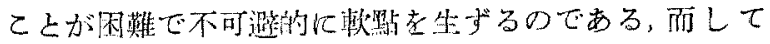
この漱點の部分は吐粒洲組織で他の部分の胙留田組織に

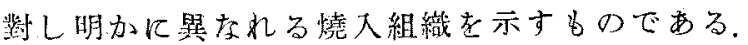
McQuaid, Ehn(1)，Grossmann ${ }^{(16)}$ 等飞依ればてれ等の軟 點は不規则な形，大さ分布志なて居るbので，正常銅の 表面怡均一に着色して居るのに㩆して翼常錩では不均一 几着色し琣點主有する，燒入中に溶解せる瓦斯が試料の

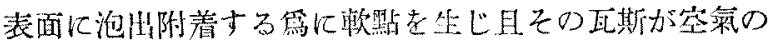
如く酸化性のものである時には著しく着色を呈すること

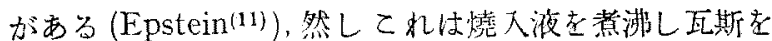
全く逸出せしめれば容易に防止出來ることで異常触の軟

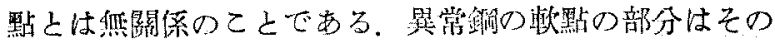
鈰の變態速度の極めて早いてとにより起れるるのである から燒入方法に依りては軟點を防止することが出來る 


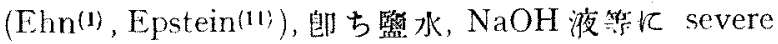
quenchingすることにより照常鎙の程度に應じて或は 完全に防此出柬或は著しくその數交減少せしめることが 出來るのである，正常銅でも濢川の正斯在溶解せる燒大

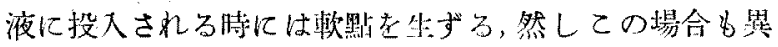
常銅の方がその數は潘に多んのである.

\section{2. 正常組織と異常組織}

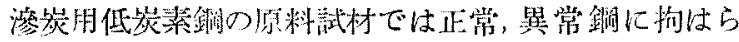

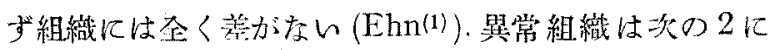
分けて考人ることが出來る。

a. 結晶粒の小なることによる翼常組織(一部の人に よつて晿へらる)

b. 波來土分解の型の異常組織

aの場合の異常組織は適栄な高溫度 $\left(1000 \sim 1100^{\circ}\right)$ て 渗炭處理するととにより容易に正常銅のbつ粠于の大さ に變へることが出來る，微細結晶粒俚銓に存在する他の

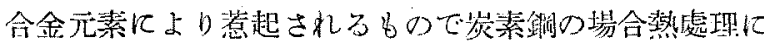
より改變出來るものである, 從來の湖究に於てての微細 結晶粒組織直ちに異常組織上若へられたことのある篇 に種々の混铜の原因になつたてとに留意せ将ば病らな

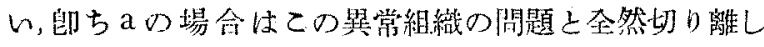

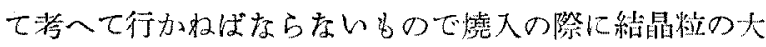

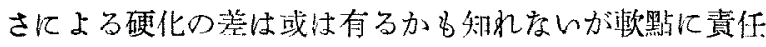

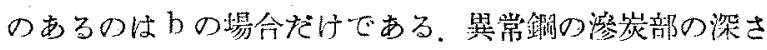

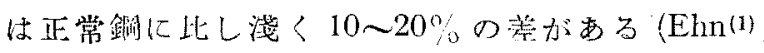

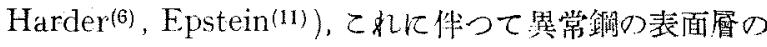

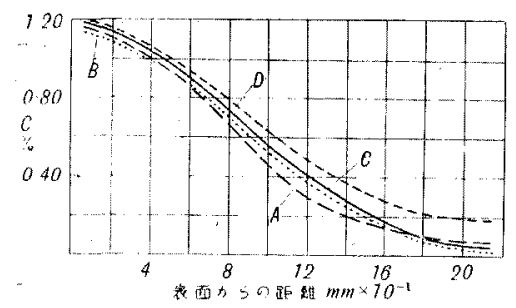

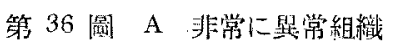
B 裁分办鼠常組織 C 徽組結晶精組瀻 $D$ 正: 賞 組 織 Mn $C$ Si $S \quad P$ $\begin{array}{lllllll}\text { A } & 0.10 & 0.06 & 0.005 & 0.024 & 0.014\end{array}$ $\begin{array}{llllllll}\text { B } & 0.37 & 0.09 & 0.004 & 0.023 & 0.018\end{array}$ $\begin{array}{lllllll}\text { C } & 0.82 & 0.14 & 0.04 & 0.024 & 0.014\end{array}$ $\begin{array}{lllllll}\text { D } & 1.64 & 0.15 & 0.07 & 0.014 & 0.020\end{array}$
最高 C 量は正 常鏩子り多以こ 乙存了。 C. $\operatorname{Herty}^{(33)}$ の) 緒

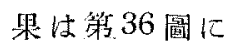
示与如人賔際的 には殆よ゙ー致し て患るが螕分力 站暴のむるつが 認め得占风名， Hertyは淩炭部

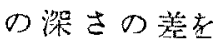
$\mathrm{Mn}$ 含有量によ り引き起される bのと洘へた。脫㞸の場合には Grossmann(16), Duftschmid(17) に上り翼常維にて特にその速度の早いこ上が 認められて居る，GrossmannはMn含有量の少ない程 脫炭速度の早いことを述べて居る。

(33) C. Herty, Min. Met. Inst. of Tech. Coop. Bull, 45 (1929), 1 .

\section{3. 正常鋼, 異常銅の物理, 化學的研究}

a. 銿の合金元素の分析化學的研究はこの問題に對し て何等の指示も與へない㥞である，偏析のある部分は異 常組織を是し而もその周图の組織は正常的である，これ はその部分が $P, S$ 或は酸化物の特に多い霉に原因される のであると云はれて居る(Ehn(1),Epstein(11)，Herty(33))， 實驗室に於て人工的に介在物を投入することに佮りてb 異常組織支生ぜしめることが出來る(Ehn(1)，Harder(6)).

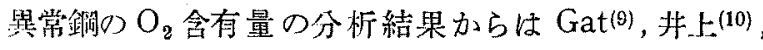
Grossmann(16)はこの種の銅では正常鐡に比し極めて多 量の $\mathrm{O}_{2}$ 在有すること老指摘し, 更に照常銓の原因を此 處に置いて居るが，Epstein(11)，Duftschmid(17)，Cornelius(26) は崤者に於て $\mathrm{O}_{2}$ 量に關しては何等の規則的な關 係のないこと孝述べて居る， $\mathrm{H}_{2}, \mathrm{~N}_{2}$ 含有量はこの現象

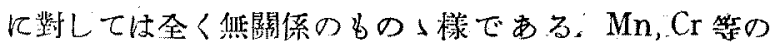

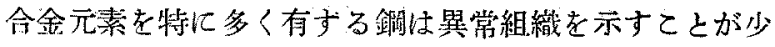
いように思はれて扂る，然してれ等の元素により變態速

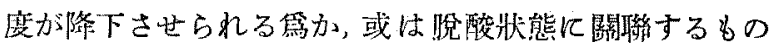
かどらかは明かにされて居ない樣である.Alに就てはMc Quaidi力 $\mathrm{Al}_{2} \mathrm{O}_{3}$ と金喰 $\mathrm{Al}$ に分けて研究したが， $\mathrm{Al}_{2} \mathrm{O}_{3}$ に 關係なくAlが1/100\%程度では正常組織であるが $1 / 10 \%$ になると暴常組織在起す，一方升上.(10)，Epstein(11)， Bain (18)，Brophy(28) 等は $\mathrm{Al}_{2} \mathrm{O}_{3}$ にり，特に不適鲎质 $\mathrm{Al}$ 脫酸により巽常性が惹起されると迅へて居る. Houdremont(17)，Cornelius(26) 祊は化學分析，分光分析の結果 $\mathrm{Fe}, \mathrm{C}$ 以外の元素の殆に゙亜い純銓に異常組織の現はれる ことを赫告して居る。

b. 機械試驗では Boylston が延び，斷面收縮率に相

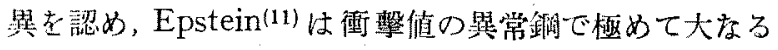
てとを見出して居るがてれれ等は異常鍈洞の有する微細結 晶粒に基く如考へて居る。

c. Harder ${ }^{(6)}$ は X線分析で璂常銅は格子常數が幾分 か大であることを見出した. F.Sillers(11) は同じ化學組 成の正常, 巽常銅に就てのX 線伵折格子には前者の結晶 粒の大なることに基く美異以外は認めなかつた。

d. $A_{1}$ 變態默に就ては Epstein(11), Houdremont(17)

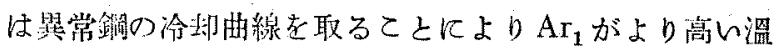
度で起ることを確めて居るが, Cornelius(26)は ${ }^{(26} r_{1}$ に就 ては大なる差畏を認めて居ないが異常銅では $\mathrm{Ac}_{1}$ が極め て低く且履歴現像の小なることを結果に出して居る。 Bain! (18) は $\mathrm{O}_{2}$ に富んだ試料では逆に $\mathrm{A}_{1}$ がより低んこと 老被告して居る。

e. 北上氏 ${ }^{(10)}$ は異常銅の電氣抵抗の測定に於てこの るのは正常錩に比し低い值を與へることを確めた。

f. Harder ${ }^{(6)}$ は異常舒闻の $\gamma$ 鐵に於けるCの溶解度が 特に減少して $\mathrm{Acm}$ 線は常の文献記載の $\mathrm{Fe}-\mathrm{C}$ 狀態圖の 
それより左上方にづれて行くと，一方 Grossmann(16)は $\mathrm{O}_{2}$ が扡鐵に於ける $\mathrm{Fe}_{3} \mathrm{C}$ 㜔散速度支大にするこるより 此鐵の $\mathrm{Fe}_{3} \mathrm{C}$ 溶解度が埥加するのであると䓂つて居る， 而して Epstein は Grossmannのての見解支支持して地 鐵に於ける $\mathrm{Fe}_{3} \mathrm{C}$ 溶解度に就ての矿究がこの現家の解沈 に大なる光明を與へるものではないかと考へて居る。

\section{4. 正常鋼，異常鋼に影嚮する處理及び兩者相互間 の變轉}

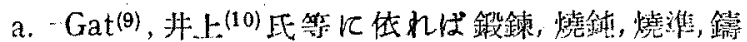
造，高溫或は常溫加工，歪加工の如き譏械處理はこの現策 亿關する限り全く無關係である。然し Epstein(11)は Norton ${ }^{(12)}$, Bureau of Standards の研労占り翼常組織の 程度の稌り激しくない当のは極めて高溫度の蓺處理その 後の空冷により，或は $\mathrm{H}_{2}$ 中の燒鈍によりその後の滲岑て は異常性の幾分か減少すること認めて居る.Sefing(14)

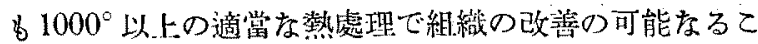
とを述べて居るが,然し Larson(13)は賽驗的にてれ然の 事筧者否定した。

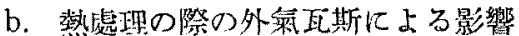

酸化性瓦斯により正常銅はそり表面庴が暴常組織に變

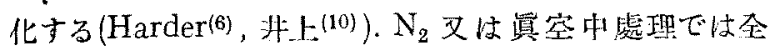
くこれによる變化は認め難い(Harder ${ }^{(6)}$ ，州上(10)，Hou一

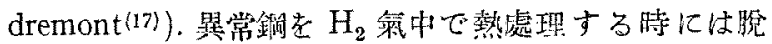

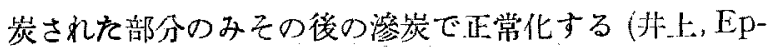
stein, 濢村). 又正常銓が酸化物，硫化物，燐化物或は容器 より不純物の混入し來る特には異常化することが啹告さ れてる居るが (Ehn, Harder)，これと反對に筫常組織を 呈する純鐵恃外部より他物質の浸入污染の熖正常化する との論文もある (Houdremont, Cornelius).

c. 滲炭劑による影響

漻岑劑を含 $\mathrm{O}_{2}$ 渗炭劑上炭化水素柔滲炭劑の 2 種類

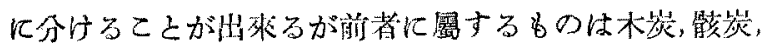

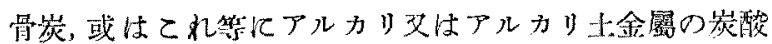

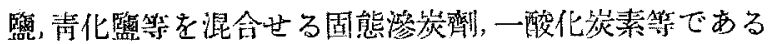
がてれ等のもの〉組織に對する作朋は全く同じである

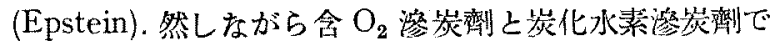
は異なつを結果考與入る (Grossmann, Bain, Brophy, 澤村, Derge $\left.{ }^{(30)}\right)$ 朗ち前者により洷炭されて巽常組織を 示しを銅も後者による時は正常化すると云ふ研染があ

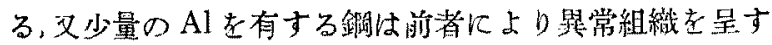
るが後者に依りては正常組織を示す，殊比 Derge の研究 では $\mathrm{Al}_{2} \mathrm{O}_{3}$ を有する試料で多炭化水溸淬炭による場合

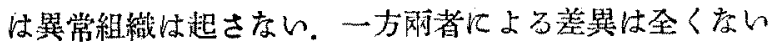
と主張して居る研究者も居る(McQuaid(24)T.Digges(32)).

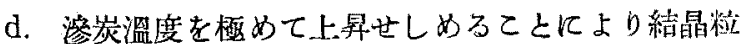
的巽常組織 女組織的翼常組織 \&正常化する (Ehn) との

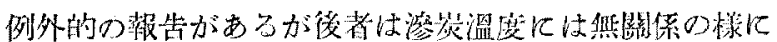

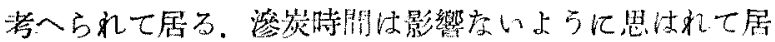
3.

e. 渗炭後す冷却速度はEhnによれば多を゙影響ない 檬に荐へられて居るが，Grossmann に依れば極度の徐 冷で正常銅でも幾分加の暴常的な組織を壮現する，半上，

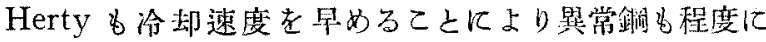
隼じて正常化するてとが出来ると述へて局る。

f. 丵入媒質による影㗽

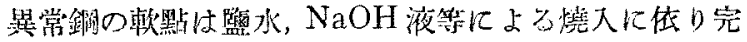
全に或は㱠ど完全に防止出來る. (Ehn, Epstein).

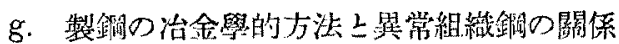

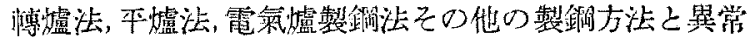

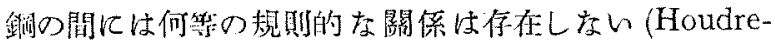

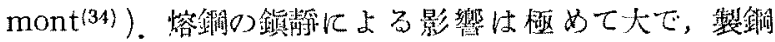
途中の各時期上り取䏮した試料の滲炭組織は初期に取出 したるのは舆常的で製銅の操作の終りに行くにつれて正

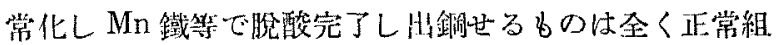

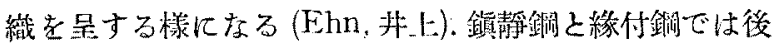
者に異常組織を有するものが多い (Epstein,Grossmann,

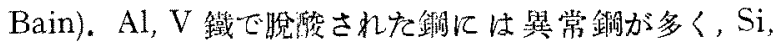

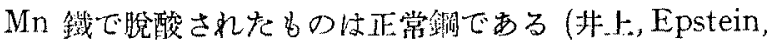
Wasmuht)，乙のことは䐋酸に上り生成した酸化物の大 さ，分价枵態が密接な關係のある栐儿考へられて居て，製

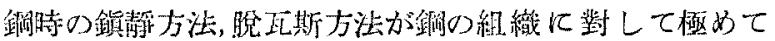
重大な役割をなすととが確である。

\section{5. 異常組織生成機構の解釋}

Ehn は酸化物は $\mathrm{Fe}_{3} \mathrm{C}$ 亿求し强い反撥性吉有してれ 等が colloidal solid solution として大洲出にある時に は $\mathrm{A}_{1}$ 變態で波棑上生成衣妨害し $\mathrm{Fe}_{3} \mathrm{C}$ 老凝固させる作

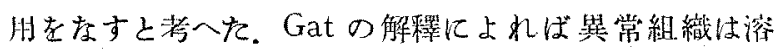
解せる $\mathrm{O}_{2}$ によりて起るるのである， $\mathrm{O}_{2}$ の你在に於て大 洲时は炭秦一大洲的之酸素一大洲时の固溶態であつて，泠 却によつて過共析部では先づ初晶の $\mathrm{Fe}_{3} \mathrm{C}$ が結晶粒界に 析出し終り炏でこの $\mathrm{Fe}_{3} \mathrm{C}$ 線に沿つて $\mathrm{O}_{2}$-大洲时が析

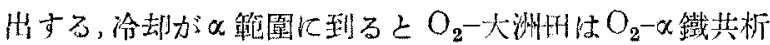
晶に存りC一大洲时は通労の波承上に變態する，而して初

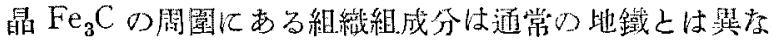
るものである. Harder は罢常辆の Acm は第2 圆に示す 如く厺上方にづれて在るものでこれにより筫常組織生成 老好都合飞說明出來ると述へて居るが Houdremont ${ }^{(34)}$

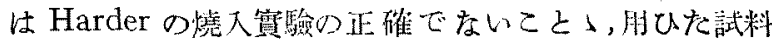

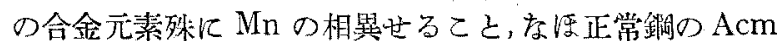
b成分が方上にづれた結果に疗つて居ることよりその

(34) E. Houdremont, H. Müller, Stahl u. Eisen, 50(1930), 1321 
考への不適當を指摘して居る. Epstein, Herty, Houdremont は翼常舧の $\mathrm{Ar}_{1}$ がより高い溫度で起るととを 確め，乙の第几波來土の $\mathrm{Fe}_{3} \mathrm{C}$ の摧散速度が大になり $\mathrm{Fe}_{3} \mathrm{C}$ は球狀化し易くなり，燒入の際に为變熊速度の早い

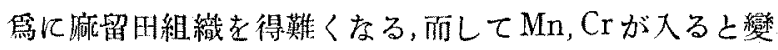
態速度の降下するれめ異常銓には成りにくっなると述へ て居名. Bain \& 異常組織は早い變態速度と早いCの摭 散速度により惹起されるものであるてとを迌べててれを 寫真によりよく說明して居る. Mahin(22) 快地鐵と $\mathrm{Fe}_{3} \mathrm{C}$ の表面張力の差上り殊に $\mathrm{O}_{2}$ の存在に上りその惹の著し くなるてとからての現象支解釋して居る.

5. 異常組織生成の原因に就て今日迄各究究者に上り 主張せられて居る學說をまとめると次の 2 にするととが
出來る。

a. 酸 素 說

b. 純 鐵 說 (Houdremont, Cornelius)

な海酸素說は

（亿）酸化物或は不溶解性粒子の存在に上る場合(Ehn, Harder, Brophy, Mahin)

(口) 鐵に周溶せる酸素 $(\mathrm{FeO})$ 飞上る場合 (Gat, 井上, Bain)

（八）㳒炭劑より供給される酸素による場合 (Bain, Grossmann, Derge)

飞分けて考へられるが，てれ等の 3 は言方迄もなく各々 獨立に主張されてるものでなく相互に關聯のあるてとは 當然である. (完)

\title{
鼠銑，鑄物用輕合金の何れを選ぶ可きか?(譒譯)
}

\author{
[M. Majer, Gießerei, 25 (1938), 424]
}

\section{山田 史 郎* 譯}

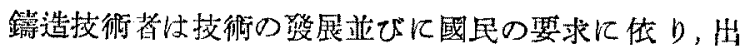
棑得る限り總括的飞解朋しなければなら好新しい問題に 常に當面して居乃。“材料を如何に選ぶ可きか?”の問 題は既に古くより鑄造家を愯ましたものであるが現在に 於てはその傾向は谷从著しくなつて居る，勿論籌造部門 程傳統がつを委とひ，然もそれ程强固で新しい力法か試

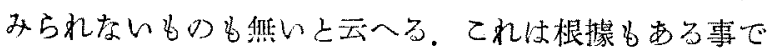
はあるが数十年桃良い之認められて隶をと云ふ理由のみ

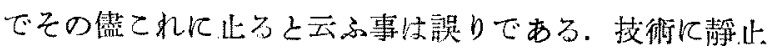

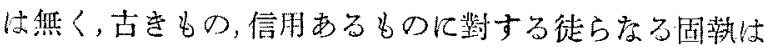
一日の退步を意味寸るものである。然し亦新しき方㳂を

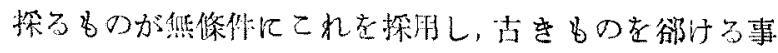
も危險な事である。

一例として，現在镨く臺所朋熱源として用ひられる燈

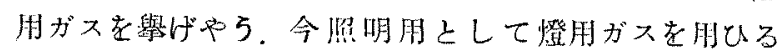

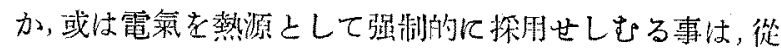
來の觀念から直ちに誤つた事となるであら5，ての例は 吾人が或るもの〉一般化に赽して非常に注意しなければ ならぬ事孝敎へるものである。

始め几述べを樣に，目的亡要求が非常に多㮔多様であ るため，原因効果侍する深知識者根據己した詳細な る研労によつて始めて事物に對する必要な明膫さが得ら

\footnotetext{
* 東北帝國大學金愿材料研究所。
}

れるものである，偖て鼣銑鑄物，輕合金鑄物の何れを選 ぶ可さかの問題が提出される時, 種 ふの湯合に於ける替

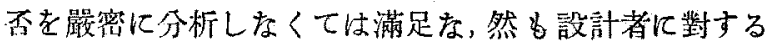
正虽なる解答は與へられない。設計者も亦現今では機械 部分を，その正賞なる要求を基準として製作して居るに

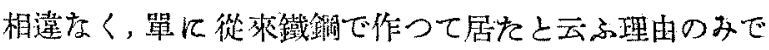
てれに止まら5と云ふ等もなく，亦材料の不足と鑄巢乃 至は粗大組織の關係から過大なる設計为行尔等はないの である．兵士の敵に對する尋問の如く，技術者は，何處か ら，如何にして，何故ときかれるに相違ない，材料学何處

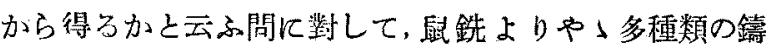
物朋鞚合金があると答へられる. 先づ一般の機械用鼠銑 を見ると强度の狳り問題とならぬ基板，蓝，保護板，導輸， 箖に從來用ひられて居た。然も高い重量が害にならな く，銑鐵が御限なく自由になる場合壮普通の事であつた が, 最近需要供給の關係により是が非でもそれ程多量な 々鐵の使用は不可能になつを。從つて必然的に輕合金構 造浜人を走らしめるものである。これは出來る文遺漏な く村料の要求の本性之性筫の知識を授けた設計者の合目 的な造成と，吾人の可能な學問と手段を唯した組織的材 料研究によつて可能になるるのである. ての問題に關し て出來るだけ鼠鉄鏟物の肉厚の均一化に努力したV.D. G» V.D.E.G の研究とか鼠銑强度の增加に盡した Dr. 